\title{
Vietnamese High school EFL Teachers' Teaching Culture through the Pilot English Textbook-English 10 and Their Perceptions of the Use of ICT to Teach Intercultural Communication
}

\author{
Minh Hieu Le ${ }^{1}$ and Cong Dan Thai ${ }^{2}$ \\ ${ }^{1}$ Department of English Teacher Education, School of Foreign Languages \\ Can Tho University, Can Tho City, Vietnam \\ ${ }^{2}$ School of Social Sciences and Humanities, Can Tho University, \\ Can Tho City, Vietnam
}

\begin{abstract}
This article intended to discuss prominent issues in teaching Intercultural Communication (ICC) to English as a foreign language (EFL)- students through the pilot English textbook-English 10 in Vietnamese high school level. The concepts of culture, language and culture, teaching and evaluation ICC and using Information Communication Technology (ICT) tools in teaching and learning ICC were defined, respectively. Next, the characteristics and components of culture would be presented as well. The relationship between language and culture would also be pointed out. Moreover, factors such as teaching, curricula, and textbooks that had an impact on the success and failure of teaching culture to EFL high school students would be examined. Besides, various uses on ICT in ICC teaching and learning would be explored. The result of data analysis from instruments: questionnaires and interviews would be presented and addressed. Additionally, the evaluation about cultural perception and ways to use ICT tools for combination into the lessons would too be described. Furthermore, the advantages and disadvantages of using ICT tools for teaching ICC in the high school language classroom would be mentioned after data analysis. Finally, some discussions and conclusion would be made.

Keywords: Vietnamese EFL high school teachers, teaching culture, teaching Intercultural Communication (ICC), Perceptions on ICC teaching,, Information Communication Technology (ICT) tools
\end{abstract}

\section{Introduction}

In the current context of globalization, English as an international language, lingua franca, and a global language (Terantino, J. 2011) is used as a means of communication in multicultural contexts. During its history Vietnamese are influenced by different cultures. As a result, Vietnamese have the opportunity to interact with a variety of languages and cultures, such as China, France, England and the United States. Up to now, English has become the second language applied for teaching to all students in Vietnam. Although the educational system has long focused on putting in great efforts to develop the functions and uses of English teaching, plenty of people still complain about their dissatisfaction with it. The findings reveal that, despite being proficient in English, many Vietnam graduates have encountered communication problems with people from different cultures. This may be due to a lack of integrated cultural content with English teaching. Therefore, cultural differences play a vital role in promoting students' competence in English. Based on the practical experiences of teachers, intercultural competence (ICC) involving teaching English directly in the classrooms encourages Vietnam teachers to put their emphasis on both linguistic competence and ICC knowledge. In the context of Vietnam, some studies which have focused on this landscape recently, have attempted to explore the effect of intercultural language learning on the development of EFL learners (Tran \& Seepho, 2016; Tran \& Seepho, 2017; Tran and Seepho, 2016a, 2016b, 2016c; Tran and Duong, 2018b; Tran and Duong, 2015d). Ho (2009) investigated culture 
in the two units in the traditional textbook utilized in the university in Vietnam with the aim of enhancing learners' cognition and behaviors to gain knowledge of culture. Tran and Seepho (2016a, 2016b, and 2016c), Tran and Duong (2015d, 2018b) discussed the importance of intercultural communicative competence, the awareness of learners and the belief of teachers and its effectiveness. They explored that the students showed positive shift in attitudes towards it. Another study concentrated on the components and the constraints having the influence on the intercultural communicative competence of EFL learners (Tran \& Seepho, 2017). With regard to the learners' attitudes towards intercultural communicative language learning, there were positive shifts in the learners' attitudes (Tran \& Seepho, 2017). However, there are few studies carried out in order to indicate and analyze the attitudes of students at high school towards the cultures in the new English textbook in Vietnamese high school contexts. One of the reasons is that these textbook are on the way to be completed and only applied into reality in some schools in Vietnam nationwide. Therefore, that is the reason why this research is implemented to help the educators have clear insights of the culture-section learning in new textbooks among high school students.

According to the pilot textbook curriculum for high schools, language and culture are included as one of all importance strands is applies for teaching intercultural communication to EFL high school students, fostering Vietnam students' understanding of the relationship between language, other cultures and Vietnam cultures, as well as their ability to apply these concepts properly in real situations. To help students understand ICC in each lesson on English textbook, Vietnam teachers need to use appropriate teaching tools, the researcher wanted to do this study named "Vietnamese High school EFL Teachers' Teaching Culture through the Pilot English Textbook-English 10 and Their Perceptions of the Use of ICT to Teach Intercultural Communication." with the two research questions:

(1) How do high school EFL teachers' teach culture through the pilot English textbook - English 10 ? and (2) What are EFL teachers' perceptions of the use of ICT to teach intercultural communication ? as described below.

\section{Review of Literature}

\subsection{What is culture}

Liddicoat, Papademetre, Scarino and Kohler (2003) define culture as a complex system of concepts, attitudes, values, beliefs, conventions, behaviors, practices, rituals and lifestyles of the people who make up a cultural group, as well as the artifacts they produce and the institutions they create (p. 45). Different with two authors above, Lee and Peterson have categorized culture into two general types: Big
"C" culture and little "c" culture (Lee 2009; Peterson, 2004). Lee (2009: 78) refers to Big "C" culture as "the culture which represents a set of facts and statistics relating to the arts, history, geography, business, education, festivals and customs of a target speech society." According to Peterson (2004), the culture relating to grand themes, is classified under Big " $\mathrm{C}$ " culture which includes the following themes such as geography, architecture, classical music, literature, political issues, society's norms, legal foundation, core values, history, and cognitive processes. The little "c" culture includes the routine aspects of life and encompasses everything as a total way of life. For Lee (2009: 78) this type of culture is "the invisible and deeper sense of a target culture" including attitudes or beliefs and assumptions.

\subsection{Teaching culture}

Nowadays, teaching culture is an important part in learning language. Through teaching and providing knowledge about cultures, EFL high school students will be felt interested with learning language. However, culture teaching cannot be generalized as teachers do in grammar teaching. Cultural teaching needs to focus on "exploration and description" which is different from teaching grammar because the rules of creating meanings are dynamic (Kramsch, 2003). Besides that, stereotype is unavoidable in culture teaching. It is one of the goals to teach learners be sensitive to cultural stereotypes (Flewelling, 1994). Stereotypes could become a factor to motivate learners in learning a FL (Dlaska, 2000). Meanwhile, it is important to both achieve balance and avoid bias in designing a cultural syllabus and it is also crucial to be aware of the images of ethnocentrism (Hardly, 2001). So, in teaching culture, teachers need to know the ways arrangement and wise choosing pictures and information needs to teach culture for EFL high school students.

\section{school \\ 2.3. Teaching language and culture at high \\ Teaching culture and language at high school} always are new topic for researchers who want to show the effectiveness of teaching ICC for students and the benefits bringing. Like Brown (2007) describes the interrelatedness of language and culture stating "that one cannot separate the two without losing the significance of either language or culture. The acquisition of a second language, except for specialized, instrumental acquisition, is also the acquisition of a second culture" (p. 189-190). Based on these findings, it is clear that language and culture learning are inextricably linked, but what role does culture play in language teaching and how is it being taught. In the study of Moore (2006) found that at least $80 \%$ of the teachers surveyed indicated they 
were teaching culture more than half of their instructional time. Although teachers have begun to incorporate more culture in the lesson, the major concern that remains is finding effective ways for integrating culture and language that prepare the learners to communicate and collaborate effectively in the 21st century - the age of cultural interference. Although multiple attempts and continuous efforts to define the term "culture," researchers have not yet come up with a single agreed-upon definition (Tang, 2006) or a common denominator, because culture is a "very broad concept embracing all aspects of human life" (Seelye, 1993, p. 15). The lack of an ICC perception will present EFL teachers' with the challenge of determining which components or segments of the target culture should be taught. Despite teaching culture may be no longer taught as basic skills, but culture is still often motive for students to learn language..

\subsection{Intercultural communication (ICC) and} teaching ICC

Intercultural communicative competence comes as a result of the need of an approach in teaching a foreign language that favors the learners' intercultural ability. Nobody can deny the advantages that communicative competence has brought to learning English as a foreign language. It is true that this competence was widely promoted in a classroom during the last decades and it focuses on bringing learners' attention to what is appropriate in a specific context in a community. This has led many researchers to evaluate learner's communicative competence and investigate the extent that the learners can interact in a wider context. The notion of intercultural communication (ICC) has long been addressed in multifarious disciplines of study such as anthropology, communication, linguistics, psychology, and sociology (Bennett, 1998). The contributions of these fields can be seen as perception, interpretation, attribution (psychology, linguistics, communication), verbal communication (linguistics, communication), nonverbal communication (communication), communication styles (linguistics, communication), and values (psychology, anthropology, sociology) (ibid.).

In general, teaching culture can be considered as a basic and vital component of the learners' acquisition of intercultural communicative competence because culture is manifested in one's attitudes, emotions, beliefs, and values. In fact, gaining these components depends on the success of the involvement of the relevant strategies, approaches, techniques and activities in the English language teaching and learning $(\mathrm{Xu}, 2016)$. But in this research, lessons is arranged logic following the basic topics from easy to hard, meaning of each lesson is compared between the culture of Vietnam with others country, with purpose help students are able to remember main idea in each cultures in pilot English textbook - English 10 through methods, strategies and ICT tools supporting. Through these approaches, researcher emphasizes the use of authentic materials and ICT tools as they play an important role in raising cultural awareness. The researcher considers teaching culture is not only about giving cultural information but also how to make students thinking, looking, learning and integrating and make them engaging in learning and so promoting cultural thinking.

\subsection{Teaching ICC through lessons in English textbook at Vietnamese high school}

Culture in general and Intercultural communicative competence in particular plays an essential role in language teaching with the purpose of developing students' communicative competence. So that, ICC needs to be paid attention to language teaching, which helps students have ability to communicative to the fullest extent and to know how to meet their communicative goals. Besides that, starting that language students can involve themselves in the authentic and functional use of the language for meaningful objectives if they are provided with ICC knowledge. In the specially cases of EFL high school students in this research, teacher need to perception the way to use ICT tools to teach ICC and how to apply ICT tools for teaching ICC for students through lessons in pilot English textbookEnglish 10 are suitable and effective.

Nonetheless, many school schools used peertutoring systems. A more skillful teacher in ICT would assist and guide another teacher who has less experience with ICT along the preparation work for teaching and learning process. As what has been discussed, there are many factors to enable the use of ICT in classroom teaching and learning. Begin with policy, follows by the supplement of all the ICT hardware and software facilities, continued by readiness and skills of teacher to integrate it into pedagogical process (Agbatogun, 2012). Besides, technical support and continuous professional development in ICT should be conducted from time to time. For instance, there are a significant number of online materials that can be integrated into traditional English lessons, such as the YouTube website, Facebook, Zalo \& Skype software. More convenient is that these applications are be able to use on computers and smartphones. To promote intercultural communicative competence in the classroom, teachers can use textbook for teaching and some ICT tools likes Facebook, YouTube, Zalo $\&$ Skype. Bringing new culture lessons into pilot textbooks is an innovation compared to old textbooks. This innovation brings many advantages for students, students be able to understand more about the cultural knowledge of countries around the 
world, students be able to aware of the difference between Vietnamese culture and other cultures, other country.

\subsection{ICT tools in teaching and evaluation}

The use of ICT in teaching and evaluation presents new challenges to teachers' understanding of subject knowledge in ICT, as well as ICC, in order to underpin the students' experience with focused learning intentions in a meaningful context. Up-to-date technology offers many methods of enhancing classroom teaching and learning (Lefebvre, Deaudelin \& Loiselle, 2006; Ghavifekr et al., 2014). According to Dawes (2001) stated that new technologies have the potential to upkeep education across the curriculum and deliver opportunities for efficient student-teacher communication in ways not possible before

\subsection{Using ICT tools in teaching and} evaluation ICC inside the classroom

One of the reasons why many people around in the world are able to read news fastly, this cause is developing of social network such as Facebook, YouTube, Zalo or Skype. Like that, almost teachers and students are used social network to find out information of examinations, recruitments, learning languages or support pages for teaching and learning languages. We can not deny the benefits of social network bringing for our life. However, in education, social networks are seem ICT tools to find out information, contact or connect with together for support teaching and learning. The process of teaching via the ICT tools for students learning English are gradually gaining popularity. So, the use of ICT tools for teaching ICC to EFL high school students has been applied at some schools in the Mekong Delta. A recent survey from the Pew Internet \& American Life Project found that 73 percent of online teens use social-networking sites. Updating their Facebook, Zalo, Skype and YouTube apps has become a regular activity for teens as is using these services to catch up on what their peers are doing. But, for the most part, teens are using social networking while they are away from school. Many schools actually ban access to services like Facebook and often configure filtering programs to block students from accessing them. But if they are able to use the appreciate time so it will be true absolutely. Using ICT tools in ICC teaching and evaluation inside the classroom are entirely possible when ICT tools are developing in real life and which are become a part of human in general and education in particular.

2.8. Using ICT tools in teaching and evaluation ICC outside the classroom

Social-networking tools aren't just for chatting on Facebook, Zalo, Skype or watching Videos on
YouTube channels. The evolving world of Internet communication (blogs, podcasts, tags, file swapping) offers students radically new ways to research, create, and learn. But, too often, schools use computers or smartphone as little more than glorified workbooks. Schools should reflect the real world we live in today. And we live in a social world. We need to teach students how to use effective ICT tools in learning, how to interact with people around them, how to be engaged, become global citizens. We need to teach students the powerful ways networking can change the way they look at education. We don't talk enough about the incredible power of socialnetworking technology like ICT tools to be used for academic benefit. Let's change students thinking about how to use social network be useful like an ICT tool in learning.

\subsection{Practicing ICT tools the teaching ICC}

Practicing ICT tools in teaching and learning are very necessary. Teacher is able to introduce ICT tools for students who help them choosing suitable ICT tools for learning ICC which is easy. However, teacher is able to teach students how to practice ICT tools correctly is very important. According to Morze, Varchenko, Smyrnova Trybulska (2015) to practice and teach for students, teachers need to understand about the process of communicating via the Internet is not traditional means of communication. No physical contact between the participants on the one hand will limit the exchange of non-verbal elements of communication, on the other hand the process of releasing a number of restrictions and conditions, such as gender, age, status, time, space on the grid, the level of financial, performance, etc.

\section{ICC}

-Teacher's practices ICT tools in the teaching

ICT tools are able to strike the perfect balance of providing information anytime and anywhere, social networking and interaction, and the ability to openly share thoughts and achievements. One popular way to use Facebook, Zalo, Skype and YouTube are to make regular updates about assignments, events, and anything going on in class.

\section{ICC \\ -Student's practices ICT tools in the learning}

Students are considered the first candidates in the revolution to apply social networking in learning. This trend is spreading and stems from students in developed countries in education and technology such as Europe, Australia and some countries in Asia. When teachers use software such as Facebook, Zalo, Skype or YouTube, their mining speed do not be compare to students, especially high school students. EFL high school students are able to guide their parents how to use social networks to search for 
information on the internet. In fact, when teachers present topics, online exercises, or share information about their lessons, students are actively engaged by students and increase the ability to learn lessons from the use of social networks. Students share personal information, links to other sites or comment on someone's post. By this way, they are able to connect together instantly. The use of social media has made it easier and faster to interact with classmates or teachers about class-related ICC topics.

\subsection{EFL teachers' perceptions of the use of ICT to teach ICC}

Teacher perceptions of ICT is important as it forms a tendency that helps them to be favorable or unfavorable towards the usage of the most modern technology in the field of education. Previous research focused on explaining technology adoption and acceptance; how technology's attributes affect an individual's perception of technology. This in turn affects the usage of specific technology and technological readiness (Porter \& Donthu, 2006) to embrace and use new technologies to accomplish goals in home, life, and at work (Parasuraman, 2000). Previous studies have stated the importance of teacher perceptions as a critical factor among teacher ICT readiness to integrate ICT into classroom teaching. The study of Onyia and Onyia (2011) sought to discover whether a significant correlation exists between perception of self efficacy and technology adoption among teachers. The findings point out a positive correlation between teacher selfefficacy and the integration of technology. There is a need to address teacher concerns and fears as they integrate technology into their classroom instruction. The results of Al Bataineh (2014) showed that teachers need to understand how to use ICT for implementing technology in social studies classrooms.

\subsection{Perceptions and perceptions on ICC} teaching

The concept of perception is defined in different ways. According to Oxford Dictionary, perception is defined as the process of becoming aware of regarding, understanding, or interpreting something and a mental impression. In addition, perception is the process whereby people select, organize, and interpret sensory stimulations into meaningful information about their work environment ( Rao \& Narayan, 1998). Moreover, Susuwele (2005) also suggested as well as external factor. Thus, people comprehend information of the world and the environment on a basic of personal experience like background knowledge that they have gained previously. Hence, perception is composed of the process of what human senses reflect the previous information knowledge (Gamond et al., 2011). In this research, perception is used to refer to teachers' understanding, awareness, how to use and practice ICT tools to teach ICC for EFL high schools students.

\section{Materials and Methods \\ 3.1. Materials}

This material used in this study was pilot English textbook - English 10. The pilot English textbook- English 10 were student books under the English pilot program issued by the MoET. The book was compiled in the direction of communication, helping students to initially formulate and develop their English communication skills, learn about Vietnamese culture and countries around the world, along with four skills of listening, speaking, reading, writing, which prioritizes listening and speaking skills. There were 2 books, and each book had 5 lessons. The topics in the book were closed and relevant to the 10th Grade regular program. The study used The Pilot English Textbook - English 10 Publisher: Vietnam Education Publishing House Publication date: July $3^{\text {rd }}, 2019$

\section{2. Methods}

There were twenty five EFL high school lecturers participating in this study consisting of eleven males $(44 \%)$ and fourteen female $(56 \%)$, all of participants from three high schools in the Mekong Delta region, South of Vietnam in academic year 2019 - 2020. The participants' age ranged from 26 to retirement with lecturers, it included: nine lecturers from 22 years old to 30 years old (36\%), eleven lecturers from 31 years old to 40 years old (44\%), three lecturers from 41 years old to 49 years old $(12 \%)$ and two lecturers from 50 years old to retirement $(8 \%)$. There were twenty four lecturers obtained an BA degree (96\%) and one lecturer obtained a master degree (4\%). There were twelve lecturers have years of teaching pilot English textbook experiences from 1 year to 2 years $(48 \%)$, ten lecturers from 3 years to 5 years of teaching pilot English textbook experiences $(40 \%)$ and three lecturers from 6 years to 10 years of teaching pilot English textbook experiences (12\%). There were twelve lecturers from 1 year to 2 years of teaching ICC in pilot English textbook experiences (48\%), ten lecturers from 3 years to 5 years of teaching ICC in pilot English textbook experiences $(40 \%)$ and three lecturers from 5 years to 10 years of teaching ICC in pilot English textbook experiences (12\%).

\section{Results and Discussion \\ 4.1. Quantitative results}

A One sample T - Test ( Table 4.1) was run to check whether there was a difference between the effect of using ICT tools of teachers in ten units through pilot English textbook - English 10 ( $\mathrm{M}=4.0$ as a high 
level ) and the test value of 4.4 as considered the high level in light of Oxford framework. The result showed that there was a significant different between EFL teacher's teaching culture with ICT tools through pilot English textbook - English 10 in 10 units ( $M=4.0$ as a medium level ) and the test value of 4.4 as regarded as the high level in light of Oxford framework was observed $(\mathrm{t}=-12.065 ; \mathrm{p}=0.000)$, which indicated that participants' perception of teachers perceptions of the use of ICT to teach Intercultural Communication through pilot English textbook Grade 10 was medium.

Table 4.1: The effect of using ICT tools of teachers in teaching ICC in ten units through pilot English textbook - English 10

\begin{tabular}{|l|l|l|}
\hline \multicolumn{3}{|c|}{ One-Sample Test } \\
\hline & \multicolumn{2}{|c|}{ Test Value =4.4 } \\
\cline { 2 - 3 } & $\begin{array}{l}\text { Sig. (2- } \\
\text { tailed) }\end{array}$ & $\begin{array}{l}\text { Mean } \\
\text { Difference }\end{array}$ \\
\hline $\begin{array}{l}\text { Using ICT tools of teachers } \\
\text { in ten units through pilot }\end{array}$ & 0 & -0.392 \\
$\begin{array}{l}\text { English textbook - English } \\
10 \text { at Vietnamese high } \\
\text { school }\end{array}$ & & \\
\hline
\end{tabular}

\subsection{Qualitative data}

Below are several typical explanations provided by the participants:

" [...] I often used videos on YouTube and send document files by Zalo for students, sometimes, I used Facebook to find out some picture relating to the topic in the lesson and show up for my students. They felt happy and attention more into the lesson. I didn't used Skype in teaching ICC because almost my students didn't used this ICT tool. My students said that: The first time, I think ICC so boring and I cannot understand the meaningful in topic but after watching video I can understand and I will visit to this place".

( Teacher 1 )

“ $[\ldots]$ I often downloaded and used videos on YouTube to introduce the topics in teaching ICC, it could help my students felt attention and understanding more about the meaningful, contents in each topic I showed. Sometimes, I send link of videos on YouTube by Zalo for my students before they come to class when I wanted them work in group and they presented by poster on class. I rarely used Facebook and Skype, because I rarely used them. Talking about the effect of using ICT tools in teaching ICC, first time, I didn't thought my students be liked them. When I given video for my students relating the topic they will learn. They could worked in group and presented some ideas about the topic. Through this activities, they could remember vocabulary, apply speaking skill to present and cooperation together."

( Teacher 2)

“ [..] I am very like using videos on YouTube to help my students can understand the meaning of topic and help them can remember some important information relates to each topic. My students felt happy when I applied this ICT tool, sometimes, I given them some questions about topic and they will present their ideas in front of the class, I thought this activities will help my student improving speaking skill and they could believe when they used speaking skill. Besides that, my students and me often used Zalo to chat and talk about the topic in next week through group on Zalo. Almost students actively participated this activities. About using Facebook in teaching ICC, I thought that was a good idea and I will use it in the future. With Skype, my student rarely used this ICT tool so I didn't used this ICT tool to teach ICC.

( Teacher 3)

4.2.1. EFL teachers perceptions of the use of ICT tools to teach intercultural communication

Table 4.2 shows that the total mean scores of the cluster on EFL teacher's teaching culture with ICT tools through pilot English textbook - English $10(\mathrm{M}=3.0)$ are medium in the scale 3 in the five degree scale.

Table 4.2. EFL teachers' perceptions of the use of ICT tools to teach intercultural communication

\begin{tabular}{|c|c|c|c|c|c|}
\hline Item $(\mathrm{N}=25)$ & $\begin{array}{l}\text { SD } \\
(\% \\
)\end{array}$ & $\begin{array}{l}\mathbf{D} \\
( \\
\% \\
)\end{array}$ & $\begin{array}{l}\mathbf{N} \\
( \\
\% \\
)\end{array}$ & $\begin{array}{l}\mathbf{A} \\
( \\
\% \\
)\end{array}$ & $\begin{array}{l}\mathbf{S A} \\
(\% \\
)\end{array}$ \\
\hline $\begin{array}{l}\text { The type of ICT tools I } \\
\text { use in teaching ICC is } \\
\text { largely dependent on } \\
\text { the lesson objectives } \\
\text { and activities. }\end{array}$ & 0 & 0 & 0 & 68 & 32 \\
\hline $\begin{array}{l}\text { The type of ICT tools I } \\
\text { use in teaching ICC is } \\
\text { largely dependent on } \\
\text { the availability and } \\
\text { accessibility at school. }\end{array}$ & 0 & 0 & 12 & 68 & 20 \\
\hline $\begin{array}{l}\text { The type of ICT I use in } \\
\text { teaching ICC is largely } \\
\text { dependent on the } \\
\text { diverse learners' needs. }\end{array}$ & 0 & 4 & 4 & 76 & 16 \\
\hline $\begin{array}{l}\text { I choose the type of } \\
\text { technology (ICT tools) } \\
\text { to teach ICC that I am } \\
\text { familiar with or } \\
\text { frequently use. }\end{array}$ & 0 & 0 & 0 & 88 & 12 \\
\hline
\end{tabular}




\begin{tabular}{|c|c|c|c|c|c|}
\hline $\begin{array}{l}\text { I only have access to } \\
\text { computers in the } \\
\text { computer laboratory. }\end{array}$ & 0 & 80 & 0 & 20 & 0 \\
\hline $\begin{array}{l}\text { I choose the type of ICT } \\
\text { tools to increase } \\
\text { learners' confidence in } \\
\text { learning ICC. }\end{array}$ & 0 & 0 & 0 & 84 & 16 \\
\hline $\begin{array}{l}\text { I allow my students to } \\
\text { use gadgets (ICT } \\
\text { devices) during the } \\
\text { lesson. }\end{array}$ & 0 & 48 & 0 & 52 & 0 \\
\hline $\begin{array}{l}\text { I choose ICT tools } \\
\text { based on the curriculum } \\
\text { or subject policies of } \\
\text { ICC part from the } \\
\text { Ministry of Education } \\
\text { and Training of } \\
\text { Vietnam (MoET). }\end{array}$ & 0 & 36 & 12 & 52 & 0 \\
\hline $\begin{array}{l}\text { I prefer using ICT on } \\
\text { my own when no-one is } \\
\text { around/watching to see } \\
\text { me making mistakes. }\end{array}$ & 24 & 76 & 0 & 0 & 0 \\
\hline $\begin{array}{l}\text { I think that using ICT } \\
\text { tools in teaching ICC is } \\
\text { a new method. }\end{array}$ & 0 & 0 & 24 & 76 & 0 \\
\hline $\begin{array}{l}\text { I don't like using ICT } \\
\text { tools (YouTube, } \\
\text { Facebook, Zalo, Skype) } \\
\text { in teaching ICC because } \\
\text { it is not useful. }\end{array}$ & 20 & 80 & 0 & 0 & 0 \\
\hline $\begin{array}{l}\text { Using ICT tools in } \\
\text { teaching ICC is NOT } \\
\text { bring any values for } \\
\text { students. }\end{array}$ & 32 & 68 & 0 & 0 & 0 \\
\hline $\begin{array}{l}\text { I lost a lot of time to } \\
\text { prepare ICT tools for } \\
\text { teaching ICC. }\end{array}$ & 8 & 40 & 12 & 40 & 0 \\
\hline $\begin{array}{l}\text { I think using ICT tools } \\
\text { in teaching ICC is very } \\
\text { difficult. }\end{array}$ & 0 & 72 & 0 & 28 & 0 \\
\hline $\begin{array}{l}\text { My students cannot } \\
\text { understand ICC lessons } \\
\text { when I used ICT tools. }\end{array}$ & 0 & 72 & 8 & 20 & 0 \\
\hline $\begin{array}{l}\text { I think using ICT tools } \\
\text { can help teachers saving } \\
\text { time on class. }\end{array}$ & 0 & 0 & 20 & 76 & 4 \\
\hline $\begin{array}{l}\text { I don't need ICT tools } \\
\text { in teaching ICC because } \\
\text { I can teach ICC through } \\
\text { book perfectly. }\end{array}$ & 0 & 80 & 0 & 20 & 0 \\
\hline
\end{tabular}

4.2.2 The benefits of integrating ICT tools in learning ICC through the pilot English textbook English 10

Here are the benificial explanaytions from EFL high school students interviewed.

“ [...] using ICT tools in learning ICC are very interested, I am able to understand the meaning of ICC topic clearly. Through videos, picture are showed by teacher, I can remember more."

( Student 1 )

“ $[\ldots]$ through leaning ICC by ICT tools, I can save time to reading topic in textbook. Pictures and videos on YouTube are very vivid and attractive. More, I can use basic skills like speaking, listening when I present ICC topic by poster after watching videos from teacher."

( Student 2 )

" [...] save time and convenient, I can find out information on my smartphone and receive document, video link and content of test from my teacher. So, we have time to prepare for test."

\section{Conclusions}

( Student 3 )

The current study describes EFL high school teachers' perception of using ICT tools in teaching ICC for high school students. It also presents EFL teachers teach the section of Communication and Culture in the pilot English textbook - English 10, and their difficulties in teaching this section as well as their solutions and suggestions for using ICT tools in teaching ICC. The study was conducted with twenty five participants who are English teachers at high schools in Mekong Delta. The two instruments used in this study to collect the quantitative and qualitative data are were questionnaire and interview.

The findings have shown that EFL high school teachers positively perceived the necessary of using ICT tools to teach cultural knowledge to high school students. They expressed that using ICT tools for teaching culture helped students avoid communication breakdown, cultural shock and conflict, which means that they can encounter with diverse cultural situations and more understand different cultures through each topic in pilot English textbook. In addition, it can help students reflect their own culture in relation to other cultures, and provide them with greater cultural sensitivity. Moreover, the effect of using ICT tools to teach ICC brought practical values which basing on teacher perception the benefits of using ICT tools, helping high school students understood topics and they are able to use basic skills they learn on class to practice what they understood in cultures topic with the support of ICT tools inside and outside the classroom follow the lesson plan of teacher. With regard to EFL high school teachers about practices and evaluate teaching ICC section in the pilot English textbook 
series, it has taken full advantage of using ICT tools to teach ICC for teaching cultural aspects and the way to evaluate activities of students when they joined.

The findings also revealed that the most common way to convey cultural knowledge is asking students to compare aspects of their own culture with those of the target culture or describe any aspect of their own culture in English through presentation by PPT, poster...etc. from easy to hard level after teacher showed videos on class for them and they must be joined activities which was designed following to plan on Zalo group or Facebook group by teacher before. In this way, students are encouraged to discover similarities and differences between their own culture and others ones. Additionally, the findings showed that teachers were not sufficiently familiar with several cultural aspects such as literature, ethnic groups, music, drama, art and so on. As a result, most students felt confident when they presented about the culture topic, they felt happy when they was practiced basic skills in learning ICC time and they liked the teacher way using ICT tools in teaching ICC, it was very interested. Besides that, some students felt hard to explain and expressed the lack of confidence when talking about these culture topics. Because they just learn reading skill, writing skill, grammar during learning English at their high school, their teachers ignored speaking skill and learning ICC like the plan in pilot English textbook. So, having some teachers still watch lightly the important of teaching ICC and speaking for high school students at Mekong Delta. It will be a great disadvantage for the students when they learn English, these thing not only decreasing confident, passion of students but also increasing the gap between learning and practicing second language during the integration period and developing learning second language for students. Moreover, they must have lost the opportunity to use ICT tools properly for learning English as well as learning ICC.

\subsection{Pedagogical implications}

The findings from this current study express several pedagogical implications for EFL teachers and administrators with regard to using ICT tools to teach the section of Communication and Culture in the pilot English textbooks - English 10.

To the EFL teachers, they should be aware of the need to integrate ICT tools in teaching language and culture through the pilot English textbook, and address culture in positive ways through organizing a wide variety of classroom activities in their own teaching practices with the supporting of ICT tools. Besides that, high school EFL teachers should be included explicit cultural aims in lesson planning to help learners develop their culture knowledge, effectively apply them in the real life and they were able to use ICT tools in teaching ICC successfully. In term of teaching materials, EFL teachers should be provided supplementary source of cultural materials on the internet and be careful in choosing information source to provide for high school students suitably.Showing videos, pictures, and films is a good way to convey cultural knowledge to learners because it provides students a chance to experience and comprehension cultural diversity thanks to memorable images. Last but not least, EFL teachers should be aware of developing students' intercultural competence through using ICT tools. Although ICC not main part in learning English with respect to high school students but it is a part motivation for students want to develop ability learn language. Consequently, students should be encouraged to understand all aspects of culture in order to communicate with foreigners better in different backgrounds.

To the administrators, the Vietnamese government has indicated the importance of intercultural competence in English curriculum, therefore, teaching communication and culture section in the pilot textbook series should be concerned to ensure that it is taught appropriately. In addition, the Department of Education and Training at Mekong Delta should organize various seminars, conferences, and workshops about teaching culture in the English textbooks through ICT tools because the participating teachers revealed that they did not have a chance to join any trainings about teaching culture through ICT tools. Moreover, the participants expressed that time for teaching both communication and culture section in one period is insufficient, and the cultural contents in textbooks are not enough interesting to engage students. Hence, the Minister of Education and Training should redesign the national curriculum for teachers to focus on.

\section{Acknowledgments}

The authors would, firstly, like to express their sincere thanks to lecturers at Can Tho University (CTU) Vietnam, those School of Foreign Languages (SFL), and espcially those from School of Social Sciences \&Humanities (SSSH), Can Tho University, CTU, for their teaching and supervisions towards the Master Program in Teaching English to Speakers of Other Languages (TESOL) and the researcher's MA classmates of Cohorts 23, 24 and presently 25. Secondly, their great thanks would go to high school EFL high school teachers and students from Kien Giang, An Giang, Dong Thap Provinces and Can Tho City, Vietnam for their kind co operations to the research through the questionnaires, and interviews face-to-face and online meetings. And finally, their great and deep thanks would go to IJASRM journal board for this paper in a series to be published to world readers, especially those interested in teaching and learning English in Vietnamese high school level on the path towards the global embarkment. 


\section{References}

[1] J. Liddicoat, L. Papademetre, A. Scarino, and M. Kohler, Report on intercultural language learning (Canberra ACT: Commonwealth of Australia, 2003).

[2] Adam, A. S. (2014). Maldivian teacher educators' cultural embodiment and the shaping of ICT habitus in their pedagogical practices. Waikato Journal of Education, 19(1).

[3] Agbatogun, A. O. (2012). Investigating Nigerian primary school teachers' preparedness to adopt personal response system in ESL classroom. International Electronic Journal of Elementary Education , 4(2), 377-394.

[4] Al Bataineh, M., T. (2014). The relationship between social studies teachers' attitudes towards technology and their perceptions of competency needed for implementing technology in their classrooms in Jordan. World Journal on Educational Technology, 6(2), 226-237.

[5] Albirini, A. (2006). Teachers' attitudes toward information and communication technologies: The case of Syrian EFL teachers. Computers \& Education, 47(4), 373-398.

[6] Almurashi, W. A. (2016). The effective use of YouTube videos for teaching English Language in classrooms as supplementary material at Taibah University in Alula. International Journal of English Language and Linguistic Research.

[7] Angers, J., \& Machtmes, K. L. (2005). An ethnographic-case study of belief, context factors, and practices of teachers integration technology. The Qualitative Report, 10(4), pp.771-794.

[8] Arnseth, H. C., \& Hatlevik, O. E. (2010). Challenges in aligning pedagogical practices and pupils' competencies with the Information Society's demands: The case of Norway. In S. Mukerji \& P. Triphati (Eds.), Cases on technological adaptability and transnational learning: Issues and challenges. Hershey: IGI global.

[9] Peterson, Cultural intelligence: A guide to working with people from other cultures, (Yarmouth, ME: Intercultural Press, 2004).

[10] Baker, W. (2012). From cultural awareness to intercultural awareness: Culture in ELT. ELT Journal, 66, pp. 62-70. doi:10.1093/elt/ccr017.

[11]Bastos, M., \& Araújo e Sá, H. (2015). Pathways to teacher education for intercultural communicative competence: teachers' perceptions. The Language Learning Journal, 43(2), pp. 131-147.

[12] Belz, J.R. \& Thorne, S.L.(2005) (Eds.), Internet-Mediated Intercultural Foreign Language Education. Aausc (American Assosiation of University Supervisors and Coordinators). Florence KY: Heinle.

[13] Bennett, M. J. (Ed.). (1998). Basic Concepts of Intercultural Communication, Selected Readings. Yarmouth, ME: Intercultural Press, Inc.

[14]Berk, R 2009, Multimedia teaching with video clips: TV, movies, YouTube, and $m t v U$ in the college classroom. International Journal of Technology in Teaching and Learning, 5(1), pp.1--21.

[15]Blair, R., \& Serafini, T. M. (2014). Integration of education: Using social media networks to engage students. Routledge.

[16] Bolton, J. (2008). Technologically mediated composition learning: Josh's story. British Journal of Music Education, 25(1), pp. 4155.

[17]Bonk, J 2009, The world is open: How web technology is revolutionizing education. San Francisco: Jossey-Bass. ISBN\\# 9780470461303. Elsevier.

[18] Boster, F, Meyer, G, Roberto, A., Inge, C \& Strom, R 2006, Some Effects of Video Streaming on Educational Achievement 1, This project was supported by a contract from United Learning Corporation, now Discovery Education. Communication Education, 55(1), pp.46--62.

[19]Brown, H. D. (2001). Teaching by Principles: An Interactive Approach to Language Pedagogy. New-York Longman.

[20] Brown, H. D. (2007). Principles of language learning and teaching. New York, NY: Pearson Education.

[21] Byram, M. (1997). Teaching and assessing intercultural communicative competence. Clevendon: Multilingual Matters.

[22] Kramsch, Language and culture (Oxford: Oxford University Press, 1998).

[23] Canale, M., \& Swain, M. (1980). Theoretical bases of communicative approaches to second language teaching and testing. Applied linguistics, 1, p 1.

[24] Chien, S.P., Wu, H.K., \& Hsu, Y.S. (2014). An investigation of teachers' beliefs and their use of technology based assessments. Computers in Human Behavior, 31, 198210.

[25] Crowe, A. R. (2007). Learning to teach with mobile technology: A teacher educator's journey. In: M. Van't Hooft \& K. Swan (Eds.), Ubiquitous computing in education 
(pp. 127-144). Mahwah, New Jersey: Lawrence Erlbaum Associates.

[26] Deardorff, D. K. (2006). Identification and Assessment of Intercultural Competence as Student Outcome of Internationalization. Journal of Studies in Intercultural Education, 10, 241-266.

[27] Deaudelin, D., \& Loiselle, J. (2006), ICT implementation stages of primary school teachers: The practices and conceptions of teaching and learning. Paper presented at the Australian Association for Research in Education National Conference, Adelaide, Australia.

[28]DLASKA, A. (2000) Integrating Culture and Language Learning in Institution-Wide Language Programs. Language, culture and curriculum, 13, 247-263.

[29] Dogancay-Aktuna, S. (2005). Intercultural communication in English language teacher education. ELT journal, 59(2), pp. 99107.59(2), pp. 99107.http://dx.doi.org/10.1093/eltj/cci023.

[30]Duffy, P 2008, Engaging the YouTube Google-Eyed Generation: Strategies for Using Web 2.0 in Teaching and Learning. pp.173--182.

[31] FLEWELLING, J. L. (1994) The Teaching of Culture: Guidelines from the National Core French Study of Canada. Foreign Language Annals, 27(2), 133-142.

[32] Fredriksson, U., Gajek, E., \& Jedeskog, G. (2009). Ways to Use ICT in Schools to Optimize the Impact on Teaching and Learning. Acta Didactica Napocensia, 2(4), pp. 21-32.

[33] Galloway, V. B. 1985. "A design for the improvement of the teaching of culture in foreign language classrooms". ACTFL project proposal.

[34] Gamond, L., N., Lemarechal, J. D., Hughueville, L., Adam, C., \& TallonBaudry, C. (2011). Early influence of prior on face perception. Neuroimage, 54(2), 1415-1426.

[35] Gebremedhin, M. A., \& Fenta, A. A. (2015). Assessing Teachers' Perception on Integrating ICT in Teaching-Learning Process: The Case of Adwa College. Journal of Education and Practice, 6(4), pp. 114-124.

[36] Ghavifekr, S., Ahmad Zabidi A. R., Muhammad Faizal A. G., Ng Y. R., Yao M., \& Zhang ,T. (2014). ICT integration in education: Incorporation.

[37] Gu, X., Meng, M., \& Li, M. (2012). A survey on teachers' perception and practice of ICC assessment of university English learners in China. Intercultural
Communication Studies, 21(11), pp. 205220.

[38] Halizah Omar, Mohamed Amin Embi \& Melor Md Yunus (2012). ESL Learners' Interaction in an Online Discussion via Facebook, Faculty of Education, Universiti Kebangsaan Malaysia, Bangi, Malaysia.

[39] Hartstein, D. (2011) How Schools can Use Facebook to Build Communities, 26 April, Mashable [online] http://mashable.com/2011/04/26/facebookfor-schools (accessed 10 October 2011).

[40] Hermans, R., Tondeur, J., Van -Braak, J., \& Valcke, M. (2008). The impact of primary school teachers' educational beliefs on the classroom use of computers. Computers \& Education, 51(4), 1499-1509.

[41] Hlasna, P., Klímová, B., \& Poulova, P. (2017). Use of information and communication technologies in primary education - A case study of the Czech Republic. International Electronic Journal of Elementary Education, 9(3), pp. 681-692.

[42] Hutchison, A. \& Reinking, D. (2011). Teachers' Perceptions of Integrating Information and Communication Technologies Into Literacy Instruction. A National Survey in the United States, Reading Research Quarterly, 46(4), pp. 312-333.

[43] Jorge, C. M. H., Gutiérrez, E. R., García, E.G., Jorge M. C. A., \& Díaz, M. B. (2003). Use of the ICTs and the perception of elearning among university students: $A$ differential perspective according to gender and degree year group. Interactive Educational Multimedia, 7, 13-28.

[44] K. Mitchell, Student Mobility and European Identity: Erasmus Study as a civic experience? Journal Contemporary European Research (2012) 490.

[45] Kennin, M-M. (2010). Differences that make the difference: a study of functionalities in synchronous CMC. ReCALL, 22(1), 3-19.

[46] Kizlik, B. (2008). Pedagogy and practice. Teaching and learning in secondary schools.

[47] Kolog, E. A. (2017). Contextualizing the application of human language technologies for counseling. Joensuu: University of Eastern Finland.

[48] Kramsch, Claire. Context and Culture in Language Teaching. Oxford: OUP, 1993. Print.

[49] Kreijns, K. (2013). What stimulates teachers to integrate ICT in their pedagogical practices? The use of digital 
learning materials in education. Computers in Human Behavior, 29(1), pp. 217-225.

[50] Kwan, R, Fox, R, Tsang, P \& Chan, F 2008, Preface to: Enhancing Learning Through Technology: Research on Emerging Technologies and Pedagogies, Forthcoming.

[51] K-Y. Lee, Treating culture: What 11 high school EFL conversation textbooks in South Korea Do, English Teaching: Practice And Critique, 8, 2009, 76-96.

[52]Lafayette, R. (1978). Teaching culture: Strategies and techniques. Washington DC: Center for Applied Linguistics.

[53] Lamy, M-N. \& Hampel, R. (2007). Online communication in language learning and teaching New York: Palgrave Macmillan.

[54]Leach, J., \& Scott, P. (2003). Learning science in the classroom: Drawing on individual and social perspectives.

[55]Lee, K. Y. (2012). Teaching intercultural English learning/teaching in world English: Some classroom activities in South Korea. English Teaching, 11(4), p. 190.

[56]Leung, L. (2004). Shyness and locus of control as predictors of Internet addiction and Internet use. CyberPsychology \& Behavior, 7, 559-570.

[57] Lipka, S. (2007) 'For professors, friending' can be fraught", Chronicle of Higher Education, Vol. 54, No. 15, p.A1.

[58] Mac Callum, K., \& Jeffrey, L. (2014). Factors Impacting Teachers' Adoption of Mobile Learning. Journal of Information Technology Education, 13.

[59] Maness, K., 2004. Teaching Media-Savvy Students about the Popular Media. The English Journal, 93(3), p.46-51.

[60] Mangubhai, F. (2005). What can EFL teachers learn from immersion language teaching ? Asian EFL Journal, 7(4), 203212.

[61]Martyn, M. (2003). The hybrid online model: Good practice. Educes Quarter y, 1, 1823

[62] Moore, Z. (2006). Technology and teaching culture: What Spanish teachers do. Foreign Language Annals, 39(4), 579-594.

[63] Morze, N., Varchenko, L., SmyrnovaTrybulska, E. (2015) "Ways of formation of effective students' collaboration skills based upon the usage of WBT', Int. J. Web-Based Communities, 2015 Vol.11 No.1 pp.25-41.

[64] Nadol'skaja, Ju. A. (2014) Multimedia training programs as a means of activation of educational activity of students at studying of German language as a second language (Educational Technology \& Society). T. 17., № 1, 347-358.

[65] O'Hanlon, C. (2007) 'If you can't beat 'em, join em", T.H.E. Journal, Vol. 34, No. 8, pp.39-40.

[66] O'Dowd, R. (2007) ( Ed.). Online Intercultural Exchange: An Introduction for Foreign Language Teachers. New York: Multilingual matters.

[67] Parent Institute (2011) Why Do Some Children Always Forget Homework?, Schoolfamily.com [online] http://www.schoolfamily.com/schoolfamily-articles/article/5986-why-dosomechildren-always-forget-homework (accessed 12 October 2011).

[68] Paulson, A. (2011) Schools Weigh Risk, Benefit of Facebook, 27 September, The Christian Science

[69] Porter, C. E., \& Donthu, N. (2006). Using the technology acceptance model to explain how attitudes determine internet usage. The role of perceived access barriers and demographics. Journal of Business Research, 59, 999-1007.

[70] Prensky, M. 2009, Make Those You Tubes!, in Educational Technology, pp.1--4.

[71]Radel, K. (2011). Blending web 2.0 in marketing courses to engage students at distance - reflections on implementing 'Facebook' as a personal learning environment. Proceedings .from ANZMAC 201,November 28-30, Perth Convention Exhibition Centre, Perth, Australia.

[72] Rao, V. S. P, \& Narayana, P. S (1998). Organization theory and behavior. Delhi: Konark Publishing Company.

[73]Rice, K, Cullen, J, \& Davis, F 2011, Technology in the Classroom: The Impact of Teacher's Technology Use and Constructivism. Retrieved from edtech2. boisestate.

[74] Schworm, P. (2010) Norton Warns Teachers Not to 'Friend' Students, 25 October, Boston Globe [online]http://www.boston.com/news/educa tion/k_12/articles/2010/10/25/norton_warns _teachers_not_to_friend_students/?page $=1>$ (accessed 10 October 2011).

[75] Science, 2 (12).

[76] Seelye, H. N. (1993). Teaching culture: Strategies for intercultural communication (3rd ed.). Lincolnwood, IL: National Textbook Company.

[77] Seilstad, B 2012, Using tailor-made YouTube videos as a preteaching strategy for English language learners in Morocco: Towards a hybrid language 
learning course. Teaching English with Technology, (4), pp.31--47.

[78] Silviyanti , T. M., \& Yusuf, Y. Q. (2015). EFL Teachers' Perceptions on Using ICT in Their Teaching: To Use or to Reject? Teaching English with Technology, 15(4), pp. 29-43.

[79] Sim, J. C., \& Theng, L. B. (2007). Teachers' perceptions of the use of ICT as an instructional tool in Mathematics and Science.

[80] Tang, Y. (2006). Beyond behavior: Goals of cultural learning in the second language classroom. The Modern Language Journal, 90(1), 86-99.

[81] Terantino, J 2011, Emerging technologies YouTube for foreign languages: You have to see this video. Language Learning $1 \&$ Technology, 15(1), pp.10--16.

\section{ISSN 2455-6378}

[82] Thomas, M. (Ed.). (2008). Handbook of research on Web 2.0 and second language learning. IGI Global.

[83] Tinio, V. L. (2003). ICT in Education. EPrimers for the Information Economy, Society and Polity. Manila: E-ASEAN Task Force/UNDP-APDIP.

[84] van Lier, L. (2000). From input to affordance: Social interactive learning from an ecological perspective. In J. Lantolf (Ed.), Sociocultural theory and second language learning (pp. 245-285). Oxford: Oxford University Press.

[85] Wang YL, Wang JP, Fu DD. Epidemiological investigation on Internet addiction among Internet users in elementary and middle school students. Chinese Mental Health Journal 2008; 22:678-682. 